\title{
PERAN AGEN PERUBAHAN DAN TEKNOLOGI INFORMASI KOMUNIKASI DALAM MENGEMBANGKAN DESA LOK BAINTAN MELALUI ECENG GONDOK MENJADI KERTAS KREASI
}

\author{
Muzahid Akbar Hayat, Sanusi dan Khuzaini \\ Magister Ilmu Komunikasi, Universitas Islam Kalimantan Muhammad Arsyad Al Banjari \\ E-mail:m.akbarhayat@gmail.com
}

\begin{abstract}
ABSTRAK. Desa Lok Baintan, Kecamatan Sungai Tabuk, Kabupaten Banjar merupakan Desa yang lebih dikenal dengan Pasar Terapung. Desa tersebut merupakan ikon dari Kalimantan Selatan yang dikenal hingga manca negara. Ketenaran desa terebut tidak diimbangi dengan keadaan Desa yang banyak tumbuh eceng gondok yang mengganggu transportasi sungai dan merusak keindahan sungai. Program Pengembangan Desa Mitra memberikan solusi dalam mengatasi permasalahan tersebut. Ditahun ketiga PPDM fokus pada menciptakan agen perubahan dan teknologi informasi komunikasi. Metode yang digunakan adalah diskusi kelompok terarah, pemberdayaan dan kontinum relationship dengan 48 peserta. Terdapat tiga katagori pada program PPDM, pertama, menciptakan agen perubahan yaitu menciptakan tutor/pelatih yang memberikan pelatihan ke desa lain yang memiliki permasalahan yang sama yaitu maraknya eceng gondok. Hasilnya terdapat 6 orang yang menjadi agen perubahan. Kedua teknologi informasi komunikasi melalui pemanfaatan e-commerce, hasilnya terdapat 28 peserta memiliki account e-commerce. Ketiga memiliki website dan pengelolanya, hasilnya terdapat website kresilung.com dan 4 orang sebagai pengelola website.
\end{abstract}

Kata kunci: pemberdayaan masyarakat; eceng gondok; teknologi informasi komunikasi

ABSTRACT. Lok Baintan Village, Sungai Tabuk District, Banjar Regency is a village better known as the Floating Market. The village is an icon of South Kalimantan which is known to foreign countries. The fame of the village is not matched by the condition of the village which grows a lot of water hyacinth which interferes with river transportation and destroys the beauty of the river. The Partner Village Development Program provides solutions in overcoming these problems. In the third year, PPDM focuses on creating change agents and information and communication technology. The method used is a focus group discussion, empowerment, and continuum relationship with 48 participants. There are three categories in the PPDM program, first, creating change agents, namely creating tutors/trainers who provide training to other villages that have the same problem, namely the prevalence of water hyacinth. As a result, 6 people became agents of change. Both information and communication technologies use e-commerce, the result is that 28 participants have e-commerce accounts. The third has a website and its manager, the result is a website kreasilung.com and 4 people as website managers.

Keywords: community empowerment; water hyacinth; information communication tecnology

\section{PENDAHULUAN}

Pasar Terapung, Lok Baintan adalah suatu pasar tradisional yang terbentuk dan berlangsung sejak dulu hingga saat ini dan merupakan refleksi dari budaya sungai masyarakat Banjar. Pasar berada di atas Sungai Martapura, Kabupaten Banjar, Kalimantan Selatan. Para pedagang dan pembeli menggunakan jukung, sebutan perahu dalam bahasa Banjar. Pasar terapung Lok Baintan terletak di Desa Lokbaintan, Kecamatan Sungai Tabuk, Kabupaten Banjar. Berdasarkan profil wilayah Desa Lok Baintan dengan luas 390 ha/m2 merupakan induk dari pemekaran desa-desa yang berada di pinggiran Sungai Martapura pada tahun 1970. Desa-desa tersebut yaitu Desa Paku Alam, Desa Lok Baintan, Desa Sungai Bakung dan Desa Sungai Pinang Lama (Normelani, 2019).

Keindahan Pasar Terapung terganggu dengan maraknya tumbuhan eceng gondok. Menurut Akbar Hayat dan Sanusi (2019) menyatakan bahwa tumbuhan eceng gondok (eichhornia crassipes) dalam bahasa Banjar di sebut "ilung". Eceng gondok adalah tumbuhan air yang tumbuh dirawa-rawa sungai dan danau. Pertumbuhan eceng gondok sangat cepat dan mampu menutupi seluruh permukaan sungai. Eceng gondok dapat berkembang biak dengan dua cara yaitu dengan tunas dan biji. Eceng gondok termasuk dalam kelompok gulma perairan yang memiliki kemampuan berkembangbiak secara cepat terutama di daerah tropis dan subtropis.

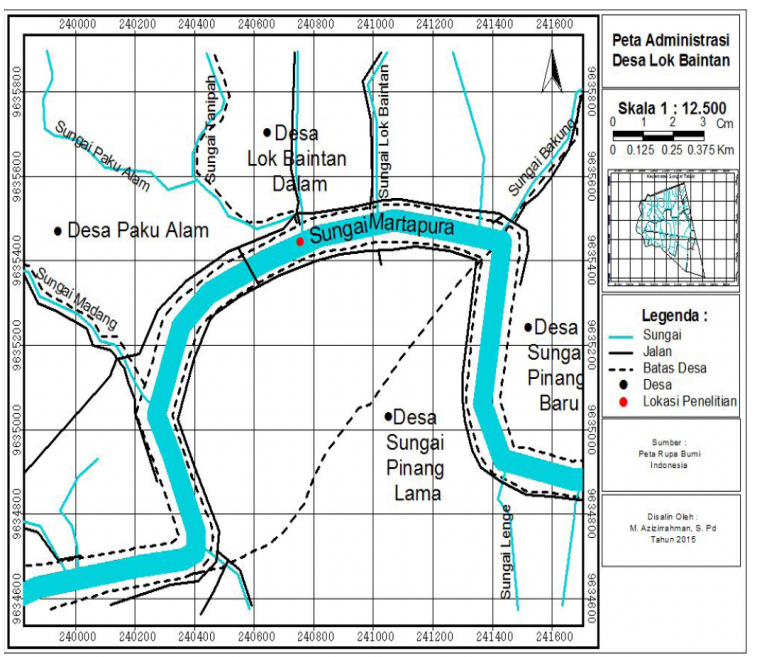

Gambar 1. Peta Administrasi Desa Lok Baintan 
Kehadiran Program Pengembangan Desa Mitra (PPDM) hadir untuk memberikan solusi pengolahan eceng gondok menjadi produk bernilai jual. Solusi permasalahan eceng gondok direspon baik oleh masyarakat Lok Baintan melalui mitra Karang Taruna dan Pemberdayaan Kesejahteraan Perempuan (PKK) mengolah eceng gondok menjadi kertas kreasi. Proses pengolahan eceng gondok menjadi kertas sudah dilakukan sejak tahun 2019 melalui program yang sama dengan tujuan masyarakat memiliki pengetahuan dan keterampilan mengolah eceng gondok menjadi kertas kreasi dari tingkat dasar hingga mahir. Masyarakat ekonomi kreatif merupakan pola pengembangan kewirausahaan yang menopang kegiatan usaha dengan pemanfaatan potensi alam (Lim H, 2008). Tahun 2021 menuntut masyarakat atau peserta yang sudah memiliki kemampuan pengolahan eceng gondok jadi kertas kreasi bisa memberikan pendidikan dan pelatihan pengolahan eceng gondok jadi kertas kreasi kepada desadesa sekitar melalui Sentra Desa Pendidikan dan Pelatihan Kertas Kreasi, kegiatan ini juga melibatkan penggunaan komunikasi digital untuk pemasaran produk dan jasa pelatihan.

Masyarakat Desa Lok Baintan, Desa Sungai Bakung, Desa Sungai Pinang Lama dan Desa Paku Alam baru mengalami pemulihan pasca terjadi banjir diwilayahnya yang terjadi Januari 2021. Hasil wawancara dengan Kepala Desa Lok Baintan disampaikan dampak banjir di desa-desa tersebut membuat masyarakat merugi, pasalnya rumah beserta isisnya mengalami kerusakan ditambah lagi hasil panen yang gagal dan tidak bisanya berjualan di pasar terapung menambah daftar permasalahan masyarakat (Bawaihi, 2021). Sehingga kehadiran program PPDM sangat membantu perekonomian masyarakat dalam menjual produk kertas kreasi.

Respon baik dari desa-desa sekitar Lok Baintan yakni Desa Paku Alam, Desa Lok Baintan, Desa Sungai Bakung dan Desa Sungai Pinang Lama menjadi tanggung jawab masyarakat Lok Baintan dalam memberikan pendidikan dan pelatihan pengolahan eceng gondok jadi kertas kreasi. Disampig itu dalam pengembangan lanjutan masyarakat Lok Baintan diharapkan mampu memanfaatkan komunikasi digital dalam hal ini website, media sosial dan e-commerce.

Pemanfaatan dan penggunaan teknologi internet diharapkan dapat memberikan manfaat yang besar terhadap dunia bisnis yang kompetitif tersebut. Usaha Mikro dan Kecil (UMK) Kreasi Ilung harus mampu bersaing dalam kompetisi tersebut adalah perusahaan yang mampu mengimplementasikan teknologi dan informasi ke dalam perusahaannya. Salah satu bentuk aplikatif teknologi dalam hal meningkatkan persaingan bisnis dan penjualan produk-produk adalah dengan menggunakan electronic commerce (e-commerce) untuk memasarkan berbagai macam produk atau jasa, baik dalam bentuk fisik maupun digital. Menurut Ridwan, dkk (2018) penggunaan teknologi tersebut, berbagai pihak yang terkait dengan perusahaan seperti investor, konsumen, pemerintah akan ikut berperan. Matangnya teknologi internet dan web, teknologi-teknologi ini meningkatkan kemampuan per usahaan yang canggih dalam hal komunikasi bisnis dan dalam hal kemampuannya berbagi informasi, selain itu berbagi sumber daya lain yang bernilai.

Upaya percepatan pemasaran produk-produk Usaha Mikro dan Kecil (UMK) Kreasi Ilung Lok Baintan memerlukan penerapan teknologi e-commerce, sedangkan website merupakan identitas digital baik individunya, prosesnya hingga produk dan jasanya. Menghadapi digitalisasi diperlukan startegi dan penerapan pemanfaatan teknologi sebagai media pemasaran dan saran promosi dalam meningkatkan daya jual produk.

Tujuan dari kegiatan ini adalah 1) Menjadikan peserta kegiatan peserta kertas kreasi menjadi pelatih atau tutor untuk masyarakat desa lain, 2) Peserta mampu melakukan penjualan produk dan paket pelatihan pengolahan eceng gondok dengan memanfaatkan teknologi komunikasi informasi berupa e-commerce dan website.

\section{METODE}

Kegiatan Pengabdian Kepada Masyarakat program Pengembangan Desa Mitra dilakukan di pelabuhan Kepala Desa Lok Baintan, Kecamatan Sungai Tabuk, Kabupaten Banjar, Provinsi Kalimantan Selatan dengan tahapan kegiatan keseluruhan pada tabel 1 sebagai berikut:

Tabel 1. Metode Kegiatan PKM Program Pengembangan Desa Mitra

\begin{tabular}{|c|c|c|c|}
\hline No & Nama kegiatan & Tanggal & Peserta \\
\hline 1. & Diskusi Kelompok Terarah & $\begin{array}{l}01 \text { Agustus } \\
2021\end{array}$ & 30 Orang \\
\hline 2. & $\begin{array}{l}\text { Pendidikan dan Pelatihan } \\
\text { Menjadi Tutor: Teknik } \\
\text { Presentasi dan Komunikasi }\end{array}$ & $\begin{array}{l}30 \text { Agustus } \\
2020\end{array}$ & 15 Orang \\
\hline 3. & $\begin{array}{l}\text { Pendidikan dan Pelatihan } \\
\text { Pengelolaan E-Commerce: } \\
\text { Mengenal manfaat dan cara } \\
\text { memiliki account e-commerce }\end{array}$ & $\begin{array}{l}31 \text { Agustus } \\
2021\end{array}$ & 48 Orang \\
\hline 4. & Pelatihan pengelolaan website & $\begin{array}{l}01 \text { September } \\
2021\end{array}$ & 4 orang \\
\hline 5. & $\begin{array}{l}\text { Pendidikan Manajemen: } \\
\text { Manajemen Produksi dan } \\
\text { Keuangan UMK }\end{array}$ & $\begin{array}{l}02 \text { September } \\
2021\end{array}$ & 48 Orang \\
\hline 6. & $\begin{array}{l}\text { Pendidikan dan Pelatihan } \\
\text { Menjadi Tutor: Public Speaking }\end{array}$ & $\begin{array}{l}02 \text { September } \\
2021\end{array}$ & 15 Orang \\
\hline
\end{tabular}


7. Pelatihan Pengolahan Eceng Gondok Jadi Kertas Kreasi tingkat dasar dan mahir

8. Pelatihan Penggunaan dan Perawatan Mesin Pencacah dan Oven Pengering Kertas Kreasi

\section{Diskusi Kelompok Terarah}

Menurut asal usul kata FGD merupakan akronim dalam bahasa inggris yang artinya Focus Group Discussion. Jika diterjemahkan secara bebas keda dalam Bahasa Indonesia berarti "Diskusi Kelompok Terarah" (Indrizal, 2014). Diskusi Kelompok Terarah dilakukan dengan tujuan penyamaan persepsi penentuan tujuan dan capaian dari kegiatan yang dilakukan. Lokai kegiatan diskusi dilakukan di kediaman Kepala Desa Lok Baintan yang diikuti oleh undangan, tokoh masyarakat, PKK dan Karang Taruna.

\section{Pemberdayaan}

Pemberdayaan Masyarakat Desa adalah upaya mengembangkan kemandirian dan kesejahteraanmasyarakat dengan meningkatkan pengetahuan, sikap, keterampilan, perilaku, kemampuan, kesadaran, serta memanfaatkan sumber daya melalui penetapan kebijakan, program, kegiatan, dan pendampingan yang sesuai dengan esensi masalah dan prioritas kebutuhan masyarakat Desa (UU No. 6 Tahun 2014 Tentang Desa). Program Pengembangan Desa Mitra ini masyarakat didampingi untuk membuat analisis masalah yang dihadapi yakni maraknya eceng gondok di bantaran sungai yang mengganggu aktifitas pasar terapung serta mengganggu tranpotasi sungai bagi wisatawan, setelah itu dibantu untuk menemukan alternatif solusi masalah tersebut yakni dengan mengolah eceng gondok menjadi produk kreatif, dengan diberikan pengetahuan dan keterampilan mengenai strategi pemasarannya.

3. Pendidikan dan Pelatihan Berkelanjutan Pendidikan dan Pelatihan continum relationship dilaksanakan dengan mengumpulkan masyarakat yang terbagi menjadi kategori pemuda karang taruna dan Ibu PKK. Tahun ini dihadiri oleh 3 (tiga) desa lain diluar Lok Baintan, antara lain; Desa Sungai Bakung, Desa Sungai Pinang Lama dan Desa Paku Alam.

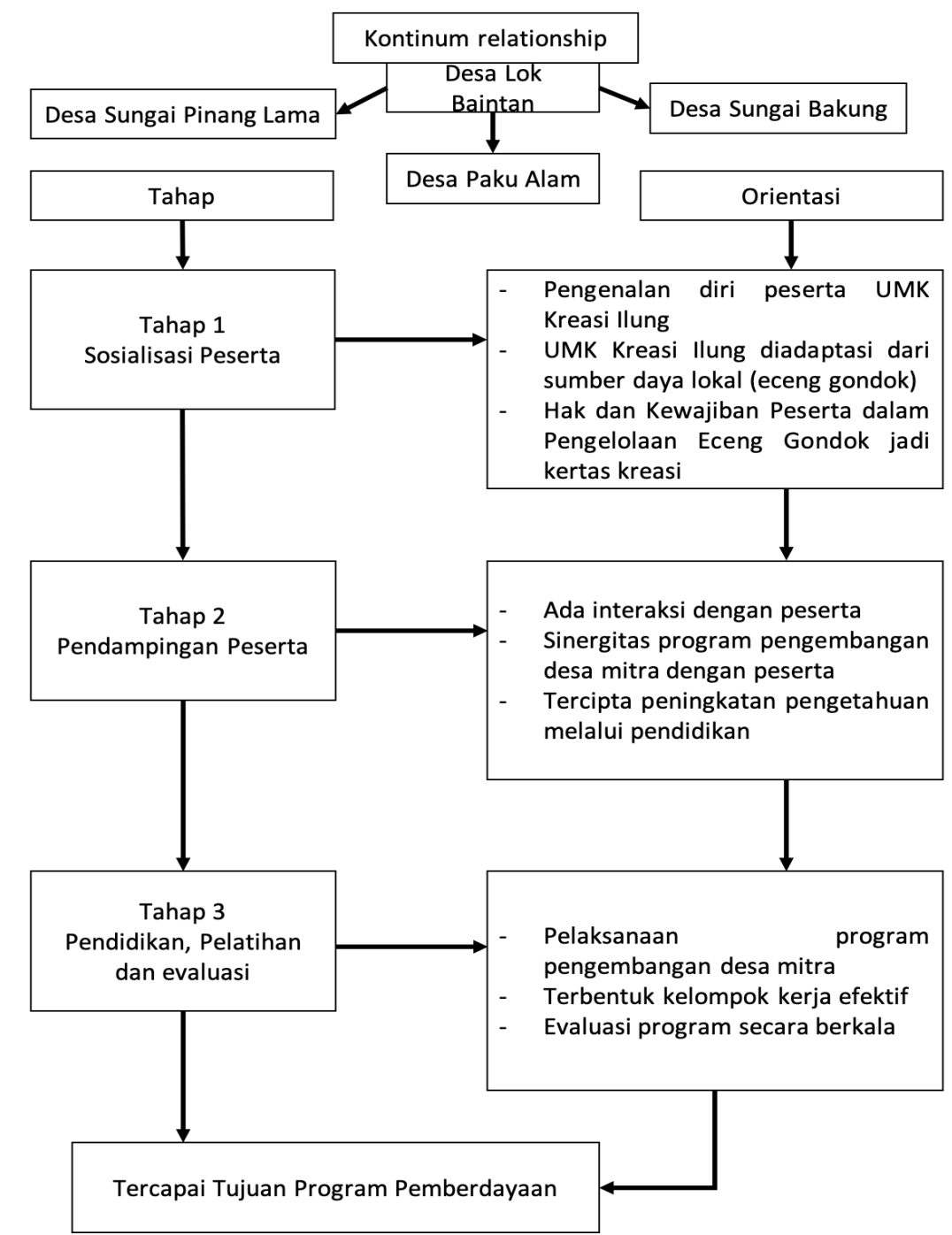

Gambar 2. Kontinum Relationship: Tahap Pemberdayaan PPDM 2021. 


\section{HASIL DAN PEMBAHASAN}

\section{Diskusi Kelompok Terarah}

Progam PPDM diawali dengan melakukan Diskusi Kelompok Terarah, hal ini dilakukan agar tedapat persamaan persepsi terhadap kegiatan yang akan dilaksanakan. Diskusi Kelompok Terarah dilakukan untuk menggali informasi yang mendalam mengenai pengetahuan, sikap dan persepsi. Selain itu untuk mengumpulkan data kualitatif perihal pemasalahan yang dihadapi sehingga bersama-sama menetapkan solusinya.

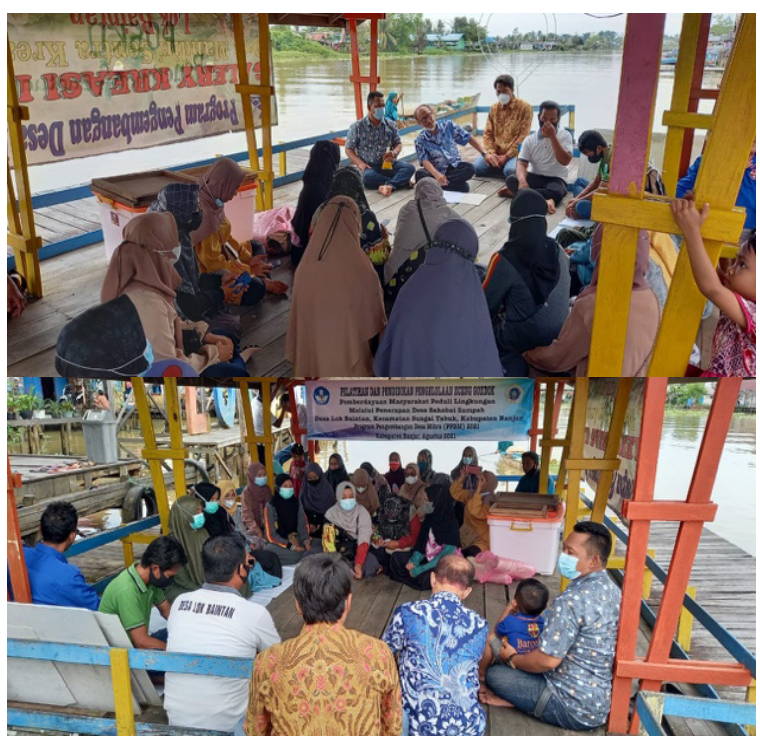

Gambar 3. Diskusi Kelompok Terarah

Dari hasil Diskusi Kelompok Terarah diketahui permasalah utama mitra yaitu dalam upaya mengurangi eceng gondok di Desa Lok Baintan ditambah 3 (tiga) desa lainnya yang mengalami permasalahan yang sama dan menghilangkan hambatan jalur sungai, hasil FGD antara lain:

a. Terdapat kerusakan alat-alat pengolahan eceng gondok jadi kertas kreasi karena banjir yang dialami pada Januari 2021;

b. Tingginya permintaan pendidikan dan pelatihan dari masyarakat Lok Baintan dan 3 Desa lain yang memiliki permasalah denga eceng gondok; Desa Sungai Bakung, Desa Sungai Pinang Lama, dan Desa Paku Alam;

c. Kebutuhan Pendidikan dan pelatihan manajemen Usaha Mikro dan Kecil Kreasi Ilung, Teknik Komunikasi Presentasi, Public Speaking dan teknologi informasi komunikasi;

d. Kebutuhan sistem penjulan secara daring (e-commerce dan website).

e. Kegiatan dilakukan dengan mengikuti protokol Kesehatan secara ketat dengan izin pemerintah setempat, yang dilakukan pada tanggal 30 Agustus 2021 sampai dengan 4 September 2021.

f. Kegiatan dilakukan di Balai Desa Lok Baintan dan Galeri Kreasi Ilung Lok Baintan.
Diskusi ini dihadiri dan disepakati oleh Kepala Desa, Ketua Karang Taruna, Ketua PKK, tokoh masyarakat dan undangan perwakilan dari Desa Sungai Bakung, Desa Sungai Pinang Lama dan Desa Paku Alam. Desa Lok Baintan merupakan desa yang masuk katagori PPKM Level 4 sehingga kegiatan diskusi kelompok terarah serta kegiatan Pendidikan dan pelatihan dilakukan dengan menerapkan protokol kesehatan secara ketat yakni wajib menggunakan masker, mencuci tangan dan menjaga jarak.

\section{Pemberdayaan}

Pemberdayaan berasal dari kata "daya" yang mendapat awalan ber- menjadi kata "berdaya" artinya memiliki atau mempunyai daya. Daya artinya kekuatan, berdaya memiliki arti kekuatan. Kata "berdaya" apabila diberi awalan pe- dengan mendapat sisipan -m- dan akhiran -an manjadi "pemberdayaan" artinya membuat sesuatu menjadi berdaya atau mempunyai kekuatan (Rosmedi \& Risyanti, 2006).

Proses pemberdayaan memerlukan pelaku perubahan (agent of change) yang berperan sebagai animator sosial agar proses pemberdayaan berjalan terus. Pelaku perubahan mempunyai peran sebagai community worker atau enabler (Ife dalam Adi, 2013). Seorang community worker harus memiliki keterampilan sebagai berikut:

a. Keterampilan fasilitatif. Seorang pelaku perubahan harus mempunyai peran sebagai animator sosial, mediasi dan negosiasi, pemberi dukungan, membentuk konsensus, memfasilitasi kelompok, memanfaatkan sumberdaya dan keterampilan, dan mengorganisir.

b. Keterampilan edukasional. Seorang pelaku perubahan juga harus mempunyai peran untuk membangkitkan kesadaran masyarakat, menyampaikan informasi, mengkonfrontasikan, dan melatih.

c. Keterampilan perwakilan. Pada posisi ini seorang pelaku perubahan diharapkan mempunyai peran dapat mencari sumber daya, advokasi, memanfaatkan media, membuat hubungan masyarakat, mengembangkan jaringan, dan membagi pengetahuan kepada masyarakat.

d. Keterampilan teknis. Adapun keterampilan teknis meliputi keterampilan untuk melakukan riset, menggunakan komputer, melakukan presentasi tertulis maupun verbal, serta kemampuan untuk mengontrol dan mengelola keuangan.

Pendidikan dan pelatihan pengolahan eceng gondok jadi kertas kreasi di Lok Baintan membentuk 6 orang pelaku perubahan yang di pimpin oleh Antung Darmansyah. 


\section{Pelatihan dan Pendidikan Berkelanjutan}

Menurut Aronson, Bostic, Huck, \& Rownsen dalam (Hayat, Sanusi dan Khuzaini, 2020), ada tiga komponen yang harus dilalui dalam pelatihan kontinum relationship. Ketiga komponen itu adalah masukan (input), proses dan keluaran (output). Pelatihan diberi menjadi tiga tahap antara lain:

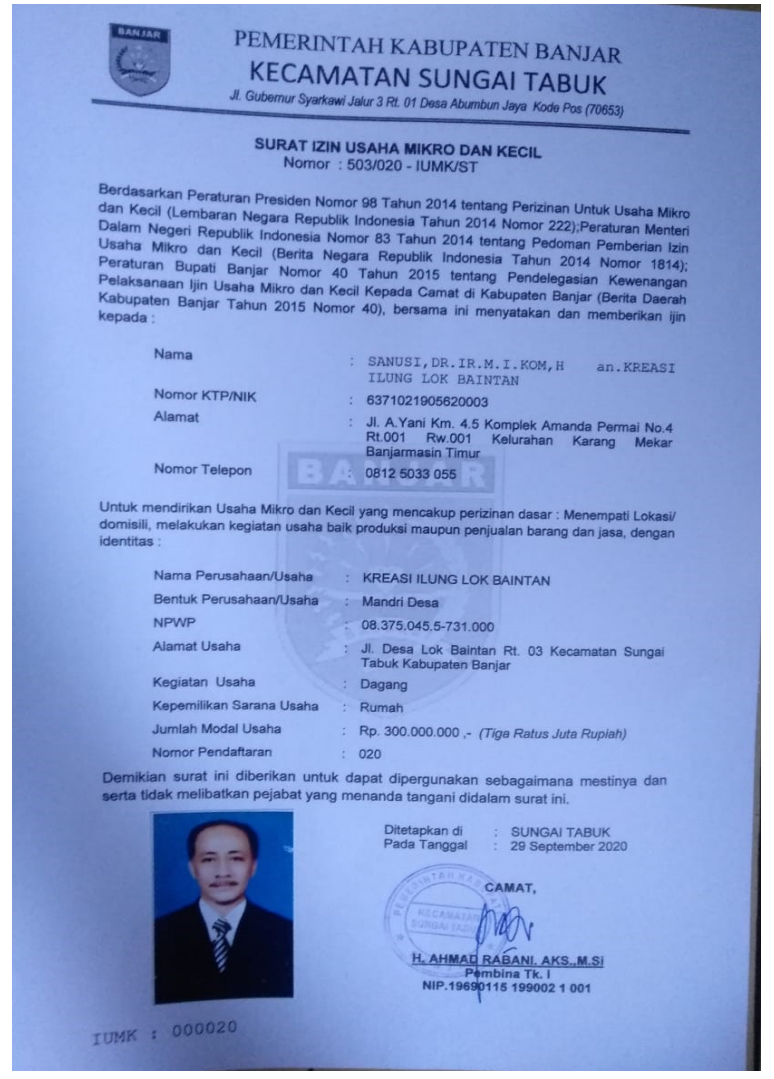

Gambar 4. Usaha Mikro dan Kecil Kreasi Ilung

a. Masukan (input) - Tahap 1 Sosialisasi Peserta

Peserta Program Pengembangan Desa mitra diberikan pengenalan tentang kegiatan Program Pengambangan Desa Mitra, antara lain:

i. Pengenalan profil Usaha Mikro dan Kecil Kreasi Ilung oleh para peserta.

ii. Pengenalan peserta yang ditentukan yaitu terdiri dari Desa Lok Baintan, Desa Sungai Bakung, Desa Sungai Pinang Lama dan Desa Paku Alam;

iii.Pengenalan narasumber untuk kegiatan yang terdiri dari pakar manajemen, pakar komunikasi dan pakar teknologi komunikasi informasi;

iv. Pengenalan agenda kegiatan Program Pengembagan Desa Mitra yakni Pendidikan dan Pelatihan Pengelolaan Eceng Gondok menjadi kertas kreasi untuk masyarakat sekitar Lok Baintan;

v. Sosialisasi tentang hak dan kewajiban peserta yang mengikuti Pengolahan Eceng Gondok jadi kertas kreasi. Hak peserta mendapatkan Pendidikan dan pelatihan pengolahan eceng gondok jadi kertas kreasi dan manfaat serta tata cara memiliki account e-commerece. Kewajiban peserta adalah mengikuti kegiatan Program Pengembangan Desa Mitra dengan membawa eceng gondok, kertas bekas, plastik bekas, kardus bekas dan datang tepat waktu.

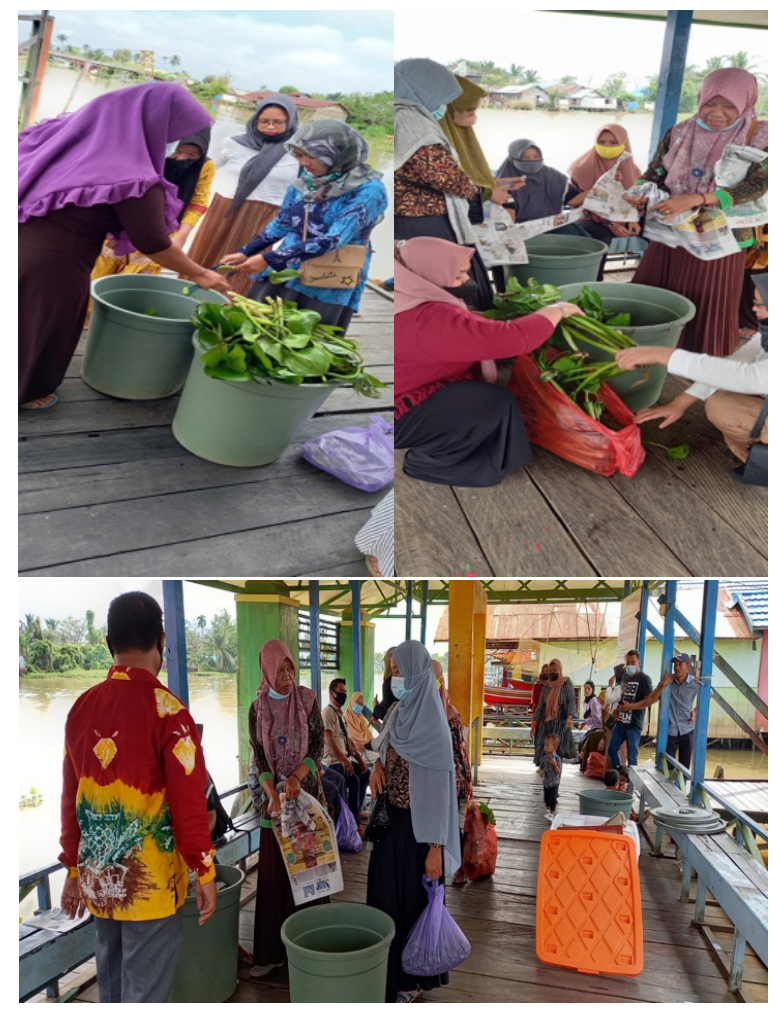

Gambar 5. Peserta membawa eceng gondok, kertas bekas, plastik bekas, kardus bekas

vi. Pengenalan bahan dan alat yang digunakan yaitu eceng gondok, lem fox, sampah kertas, sampah kardus, sampah plastik, clear cat dan air. Pengenalan alat: mesin pencacah, blender, rakel, papan cetak, bak besar, oven pengering.

b. Proses (process) - Tahap Pendampingan Peserta

Merupakan proses pendampingan melalui interaksi dan pendidikan peningkatan pengetahuan peserta:

i. Interaksi dengan peserta dengan melakukan Diskusi Kelompok terarah dan Pendidikan dan pelatihan.

ii. Kegiatan Program Pengembangan Desa Mitra merupakan programyang singergi dengan program pemerintah dalam mengatasi eceng gondok yang banyak mengganggu wilayah Kalimantan Selatan khususnya Lok Baintan - Pasar Terapung yang menjadi icon internasional.

iii.PendampingandilakukandalambentukPendidikan dalam upaya peningkatan pengetahuan.

c. Luaran (output) - Pendidikan, Pelatihan dan Evaluasi Pendidikan dan pelatihan (diklat) dibagi menjadi tiga kategori, antara lain:

i. Pertama untuk menjadikan agen perubahan sebagi Tutor/Pelatih: peserta yang pernah mengikuti 
kegiatan pengolahan dari tahun 2019 dari tingkat dasar dan mahir diberikan Pendidikan dan pelatihan untuk menjadi agen perubahan sebagai tutor/pelatih. Dari Hasilnya terdapat 6 orang yang berhasil menjadi tutor atau pelatih yang terdiri dari 15 perserta yang mengikuti diklat tersebut.

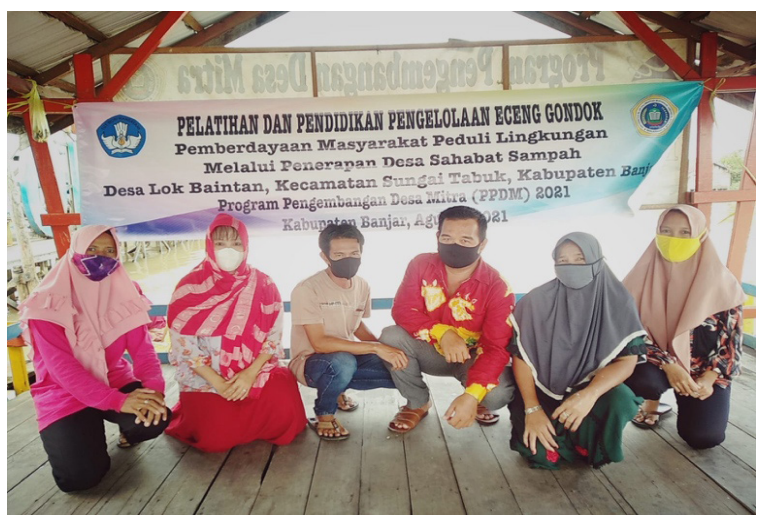

Gambar 6. Agen Perubahan (tutor/pelatih) kiri ke kanan Arbainah, Kasmaliah, Sarwani, Antung Darmansyah, Sudah dan Mirna

Pelaku perubahan memiliki tanggung jawab mendidik dan melatih masyarakat Desa lain sekitar Lok Baintan yang memiliki permasalahan yang sama yaitu sungai terganggu dengan adanya eceng gondok. Pelaku agen perubahan sudah memiliki keterampilan fasilitatif, edukasional, dan perwakilan. Namun masih memiliki kendala dalam penguasaan teknis dalam penggunaan komputer dalam rangka pemasaran daring baik e-commerce maupun website.

ii. Kedua e-commerce: adalah diklat yang diberikan perserta agar dapat memiliki account e-commerce untuk memudahkan penjualan produk hasil eceng gondok jadi kertas kreasi. Hasilnya dari 48 peserta terdapat 28 orang memiliki account e-commerce.

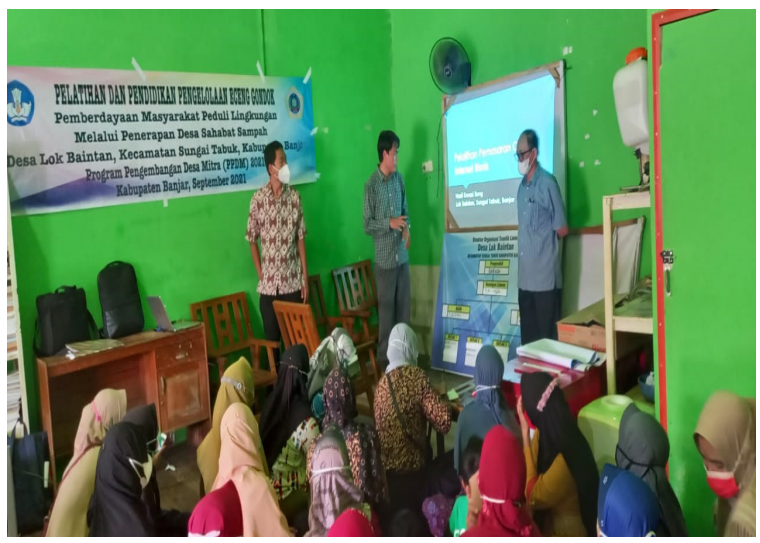

Gambar 7. Pendidikan dan Pelatihan e-commerce

iii. Ketiga pengelola website: berdasarkan hasil FGD dibutuhkan website tersendiri yang digunakan untuk penjualan produk kreasi ilung sehingga dibuatlah website kreasilung.com. Untuk pengelolaanya dibutuhkan peserta yang mampu mengelola website.

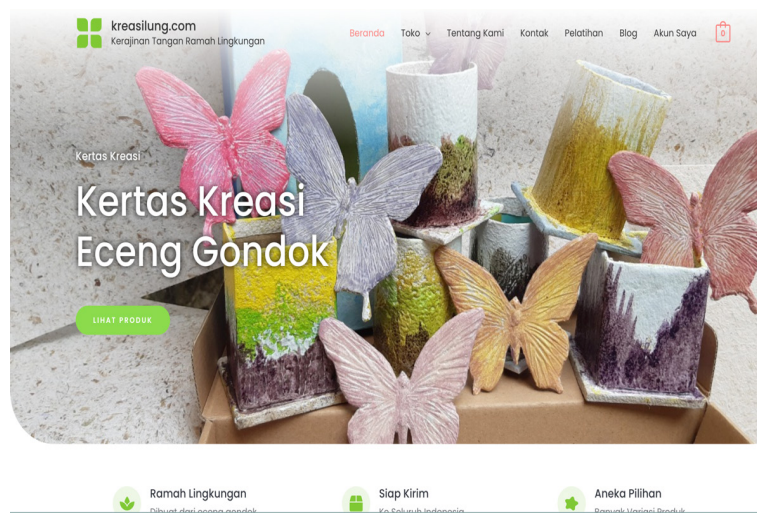

Gambar 8. Website kreasilung.com

Peserta dalam kegiatan ini dipilih dan direkomendasikan oleh Kepala Desa. Dibutuhkan orang yang memahami sedikit pengetahuan dengan internet dan website. Hasilnya terdapat 4 orang yang berhasil menajdi pengelola website kreasilung.com.

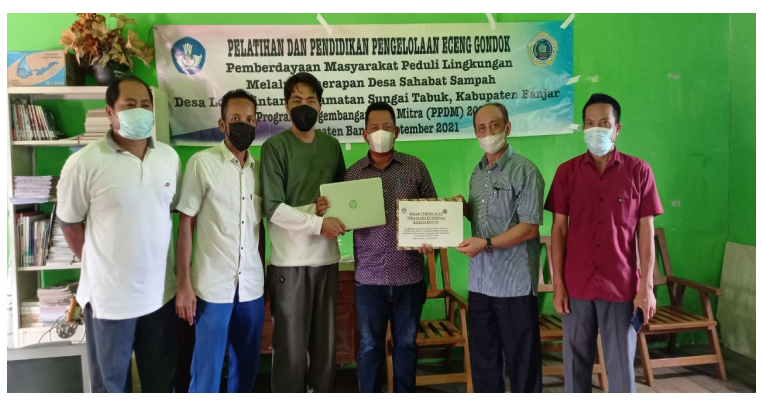

Gambar 9. Pengelola Website kreasilung.com

\section{SIMPULAN}

Program Pengembangan Desa Mitra di Desa Wisata Lok Baintan melalui pemberdayaan masyarakat Desa Sahabat Sampah, yang fokus pada pemanfaatkan eceng gondok menjadi kertas kreasi di nilai efektif dan bermanfaat bagi masyarakat Desa Lok Baintan khususnya para peserta. Pada masa pandemik seperti ini program ini menjadi alternatif dalam meningkatkan kesejahteraan peserta. Kehadiran tutor/pelatih dari desa Lok Baintan membantu Desa lain yang memiliki permasalahan yang sama sehingga tidak tergantung lagi dari tutor atau pelatih dari luar Kalimantan Selatan.

Program pengabdian kepada masyarakat melalui program Pengembangan Desa Mitra diharapkan mengurangi eceng gondok, sampah plastik, sampah kertas dan sampah kardus di Sungai Martapura khusunya sekitar Desa Lok Baintan. Keberadaan galeri diharapkan mampu menjadi daya tarik wisatawan asing maupun lokal untuk membeli produk kertas kreasi eceng gondok. Selian itu dengan adanya teknologi informasi komunikasi melalui website kreasilung.com dapat membantu penjualan produk yang dihasilkan. 


\section{UCAPAN TERIMAKASIH}

Kegiatan pengadian kepada masyarakat ini didanai oleh Kementerian Pendidikan dan Kebudayaan Direktorat Jenderal Pendidikan Tinggi, Riset dan Teknologi melalui Program Pengembangan Desa Mitra. Program kepada masyarakat didukung juga oleh beberapa pihak antara lain; LPPM Universitas Islam Kalimantan (Uniska) Muhammad Arsyad Al Banjari, mahasiswa yang terlibat, Bapak Bawaihi selaku Kepala Desa, Ibu Kumala selaku ketua PKK, Antung Darmasnyah selaku Ketua Tutor Kreasi Ilung, dan masyarakat Desa Lok Baintan. Atas dukungan dan kerjasamanya Penulis mengucapkan banyak terima kasih pada pihak-pihak terkait diatas.

\section{DAFTAR PUSTAKA}

Hayat, Sanusi, dan Khuzaini. (2020). Pemberdayaan Masyarakat Melalui Penerapan Pengembangan Desa Lok Baintan Lewat Inovasi Eceng Gondok Menjadi Kertas Kreasi. Dharmakarya: Jurnal Aplikasi Ipteks Untuk Masyarakat Vol. 9 No. 3 Hal. 157-162
Ife, Jim. (2013). Community Development in an Uncertain World. Cambridge: Cambridge University Press.

Indrizal, E. (2014). Diskusi Kelompok Terarah Focus Group Discussion (FGD). Jantro: Jurnal Antropologi Vol. 16 No. 1 Hal 75-82.

Lim, H (2008). SMEs For Development Policy. Enviroment and Challenges an Singapore, Singapore Institute For International Affairs.

Noermelani, E. (2019). Kearifan Lokal Pasar Terapung dalam Perspektif Pengembangan Pariwisata. Malang: Kota Tua.

Ridwan, H, Masrul dan Juhaepa. (2018). Komunikasi Digital Pada Perubahan Budaya Masyarakat E-Commerce dalam Pendekatan Jean Baudrillard. Jurkom: Jurnal Riset Komunikasi Vol. 1 No. 1 Hal 99-108.

Rosmedi \& Risyanti, R. (2006). Pemberdayaan Masyarakat. Sumedang: Alqaprit Jatinegoro. 